\title{
Towards Social Network Sites Acceptance in e-Learning System: Students Perspective at Palestine Technical University-Kadoorie
}

\author{
Mohannad Moufeed Ayyash ${ }^{1 *}$, Fadi A.T. Herzallah ${ }^{2}$, Waleed Ahmad ${ }^{3}$ \\ Department of Business Administration and E-commerce \\ Palestine Technical University, Kadoorie \\ Tulkarm, Palestine
}

\begin{abstract}
This study aims to examine social network sites acceptance in an e-Learning system and to propose a model encompassing determining factors that affect students' intentions to use social network sites in the e-Learning system. The proposed model was built based on the Technology Acceptance Model (TAM), perceived enjoyment, social influences, and perceived information security from the literature review. The quantitative method of data collection using a questionnaire survey is used in the current study. The data analysed using a structural equation modeling (SEM) approach through partial least square (PLS) software version 3. The results indicated that perceived ease of use, perceived usefulness, perceived enjoyment, social influences, and perceived information security has a significant and positive impact on student's acceptance of social network sites in an e-Learning system at Palestine Technical University-Kadoorie. Theoretical and practical implications discussed.
\end{abstract}

Keywords-Social network sites; e-Learning system; perceived usefulness; perceived ease of use; perceived enjoyment; social influence; perceived information security; Palestine

\section{INTRODUCTION}

Social network sites are becoming a stable part of each individual's life, especially student societies [1]. It manages to transform the lifestyle of youth people while becoming one of the natural means of communication and entertaining [2]. Social network sites facilitating and creating knowledge sharing and eventually moving a speaking into a discussion, for example, by an institution to customers [3], [4]. Using social network sites in e-Learning has improved students study methods. Therefore, numerous academic institutions have exploited opportunities to use social network sites as a novel technology to cultivate their learning provision and stay competitive by attracts new students [5], [6]. In developing countries, e-Learning has the potential to snowballing demands for education as well to relieve a decrease in the competent tutors [7].

Furthermore, in the last era, research efforts have been augmented so that successful perceptions of social network sites use for learning undertakings could emerge [2]. Some researchers like [7], [8], and [9] found the positive effect of social network sites on the learning process that leading to a higher level of performance. On the other hand, the utilitarian nature of social network sites is still unclear [7], [10]. Also, despite the numerous possible advantages of including social network sites into learning, there is a massive difference between the level of positive perceptions of social network sites and the level of applied usage [11]. According to previous research, there is a dearth of studies on users' perspective on similar technologies in developing countries [12], more precisely in the Arab countries [13], [14]. Consequently, there is a need to assess the factors that can affect the use of social network sites in Arab countries [15].

The present study is considered a notable exertion since it determines factors impacting social network sites acceptance in e-Learning in Palestine as a developing country. Therefore, the objective of this study is to suggest a model for social network sites acceptance encompassing determining factors affecting students' intentions to utilise social network sites in the eLearning system. Hence, the determination of the factors that can affect social media networks acceptance in e-Learning can help universities in enhancing students learning quality. Therefore, the researcher's stimulus to conduct this study includes the dire need for shaping the factors that affect student's acceptance of social network sites in e-Learning to meet the pioneering learning development. Hence, the critical question of this study is: what are the factors that are affecting student's acceptance of social network sites in the e-Learning system at Palestine Technical University-Kadoorie?

\section{LITERATURE REVIEW}

\section{A. e-Learning in Palestine}

The progression of Information and Communication Technology (ICT) makes this world a global village [16]. Therefore, education institutions are acceptance the cuttingedge (ICT) to be in line with the global development in education systems. The progress growth in ICT possibly increases creativity between students through e-Learning. Nevertheless, the implementation of ICT is still in its infancy stage across most of the Arab world [15]. Also, in the context of developing countries, e-Learning still faces a high rate of failure [15], [17]. Accordingly, Palestinian educational institutions are required to cover all difficulties faced by students in the acceptance of e-Learning.

Palestine is characterised as a fighting area in the Middle East district with mobility constraints [16], [18]. Palestine is separated into small portions divided by protection boundaries

*Corresponding Author 
that harmfully impact the education scheme [18]. Education sector expansion faces numerous hindrances due to the constant of Palestinian Israeli conflict. Therefore, e-Learning is a priority instead of a luxury to develop the quality of learning for students in Palestine [16]. Consequently, technology incorporation is the most significant implication in conflict zones, with a lack of learning resources [17]. Palestinians consider the development of technology as a crucial tool for their existence, justifying their daily complications, enabling the crises, improving the equity of using technology between students in both public and higher learning [16], [18] [19]. Therefore, this research examines social network sites as an effective e-Learning tool, through determining the factors affecting student's acceptance of social network sites in eLearning in Palestine at Palestine Technical UniversityKadoorie.

\section{B. Social Network Sites Acceptance and e-Learning}

Social network sites have a profound influence on the communications way these days [20]. Social network sites offer desirable capabilities, comprising send messages, knowledge share, information access, research, and chat [21], [22]. Elkaseh [23] stated that social network sites usage in universities could have a positive influence on learners' educational results. Moreover, convinced researchers such as [24], [8] indicated that the use of social network sites in writing homework had a positive effect on their degree of education.

Owing to the introduction of ICT, it is now imperative that educational institutions around the world, especially in developing countries such as Palestine leverage social network sites usage in e-Learning. As well as, it has been noted that converting from traditional education to e-Learning has augmented in the present-day. Moreover, recent research has revealed a high level of willingness amongst students to use social network sites in learning [25], [26]. Therefore, this study focuses on the factors affecting a student's acceptance of social network sites in the e-Learning system in Palestine.

The rest of the paper is organised as follows: Section II presents the study literature review that revealed e-Learning in Palestine and social network sites acceptance, Section III reviews a theoretical foundation of the study, Section IV presents research model and hypotheses development, Section V presents method of the study, Section VI presents data analysis and results, Section VII discusses data analysis and findings. Finally, we conclude in Section VIII.

\section{ThEORETICAL FOUNDATION}

\section{A. Technology Acceptance Model}

TAM is the most models used in predicting and explaining user's attributes that affect his/her acceptance behaviour to pioneering technologies because of its strength, ease, and suitability [27]. In TAM, perceived usefulness and perceived ease of use determine a person's perspective on using technology and drive a person's intention to accept the technology [28]. Additionally, the acceptance of information technology based on the user's perceived usefulness and of perceived ease of use of these technology [29], [30]. In brief, TAM main idea is summarised in individuals accept or reject information technology based on his belief that using this technology can help in completing jobs more successfully (perceived usefulness) and in less exertion (perceived ease of use) [30]. Overall, users' awareness perceived usefulness, and perceived ease of use are the critical factors in construction technology acceptance models [30], [31]. Additionally, before an understanding of the advantages of new technology, researchers need to recognise how students use them through TAM [32]. Therefore, the researchers need to understand student's acceptance of novel technology such as social network sites in the e-Learning system.

\section{B. Perceived usefulness and Perceived Ease of use}

Perceived usefulness is the degree to which the user believes that using a specific system is useful and will enrich performance [30]. In contrast, perceived ease of use refers to the degree to which a user believes that using a specific system is easy and not require much effort [30]. Previous studies found that perceived ease of use has positive effects on behavioural intentions to use [33], [34]. Perceived usefulness and perceived ease of use have been scrutinised to predict behavioural intentions to use social network sites [35]. Moreover, numerous research applied TAM in e-Learning and found that perceived usefulness and perceived ease of use have a significant influence on user behavioural intentions to use eLearning [36]. Therefore, perceived usefulness and perceived ease of use are essential factors that affect student's intentions to use social network sites in e-Learning. Hence, it postulated that:

H1. Perceived usefulness will positively affect student's acceptance of social network sites in e-Learning at Palestine Technical University-Kadoorie.

H2. Perceived ease of use will positively affect student's acceptance of social network sites in e-Learning at Palestine Technical University-Kadoorie.

\section{Perceived Enjoyment}

Technology acceptance can be affected by the perceived enjoyment [37]. According to indicate how students perceive the diverse activity or services to be entertaining in them irrespective of any results that may be expected [38]. In the context of learning, a learner's particular feelings of enjoyment, inclination, and feeling play critical roles in clearing up user acceptance of e-Learning [39]. User behavioural intention concerning social network sites is often determined by the degree of perceived enjoyment when using social network sites [40]. Furthermore, enjoyment is a factor that determines the intention of users to use social network sites [41]. In this study, perceived enjoyment means that students use of e-Learning system through social network sites in a method that develops their learning competencies. Nevertheless, the student's perceived enjoyment through the use of social network sites is being scrutinised [42]. Therefore, it postulated that:

H3. Perceived enjoyment will positively affect student's acceptance of social network sites in e-Learning at Palestine Technical University-Kadoorie. 


\section{Social Influence}

Social influence is an important factor affecting online user behaviour [43]. Furthermore, social influence affecting the user's intentions to use information technology [32], [44]. Therefore, social influence has existed extensively scrutinised in the information systems study. Wang [45] defined social influence as individual user's attitudes, beliefs and behaviour's are influenced by exhortation others. According to Maryam [46], social influence has positive effects on the user's intention to accept novel technologies such as social network sites. Based on the above discussion, it postulated that:

H4. Social Influence will positively affect student's acceptance of social network sites in e-Learning at Palestine Technical University-Kadoorie.

\section{E. Perceived Information Security}

Perceived information security plays a substantial role in information technology adoption and usage [47]. Luo et al. [48] defined perceived information security as individuals believe that private information will not be watched, kept and tamper throughout work sessions by illegal gatherings in a way reliable with their confident anticipation. Generally, the users of social network sites supply a lot of their individual information online, and the threat that this information could be misused is high in social network sites [49]. Moreover, perceived information security considered as the primary concern between users' through online existence [50], [51]. Therefore, perceived information security appears to lead students to leave the use of new technology, at which point eLearning may be a failure. Therefore, educational institutions should take this dangerous concept into account to ensure students usage of the e-Learning system. Consequently, perceived information security is an essential factor affecting student's acceptance of social network sites in e-Learning. Based on the above discussion, it postulated that:

H5. Perceived information security will positively affect student's acceptance of social network sites in e-Learning at Palestine Technical University-Kadoorie.

\section{RESEARCH MODEL}

Social network sites are an important tool for business organisations, so, it is crucial for education institutions to use this tool in learning. It is essential to realise that educational institutions need a strategy to increase their enrolment and enhance learning. Previous studies showed that students have a high level of willingness to use social network sites in learning [26], [27]. Social network sites are able to improve student's ability to achieve in the fulfillment of learning activities [31], [52]. The acceptance of social network sites have been scrutinised by various researchers using one of the numerous existing acceptance models [47]. Nevertheless, e-Learning adoption needs to be considered in the context of an information system [53]. Likewise, TAM has been mostly used in literature to ratify information systems adoption [53], [54], [55].

The emerging studies in the arena of social network sites are trying to identify the factors that help the users to accept social network sites as a novel technology in a different context such as e-Learning. However, according to Maryam [47], there is limited research in the acceptance of social network sites. Furthermore, no research has yet focused its caution on social network sites acceptance in e-Learning in Palestine via the combination of perceived usefulness, perceived ease of use based on TAM, and perceived enjoyment, social influence, and perceived information security based on literature review. Based on these aspects, this study derives the theories forming the base of the creation of the research model for social network sites acceptance including ascertaining factors that impact intention to use social network sites in the e-Learning at Palestine Technical University- Kadoorie. The research model is illustrated in Fig. 1.

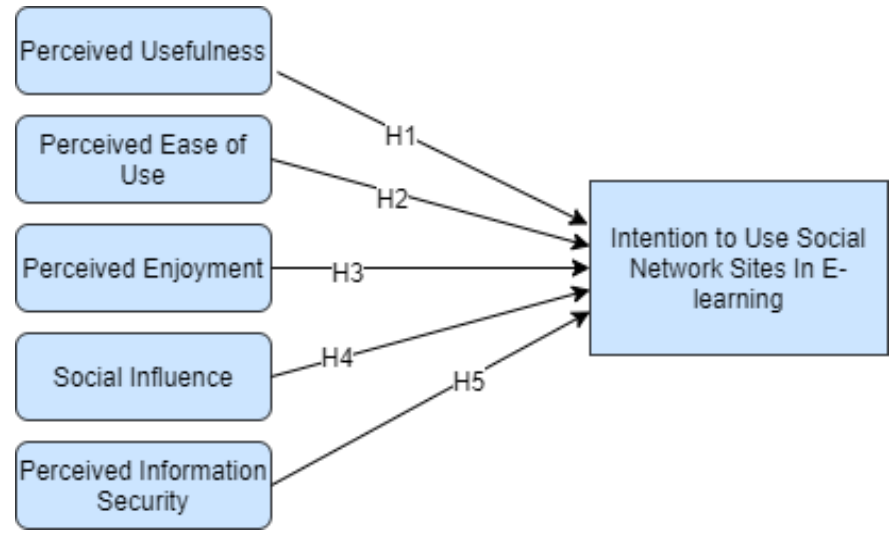

Fig. 1. Research Model.

\section{METHOD}

The aim of this study is to examine social network sites acceptance in an e-Learning system and to recommend a model for social network sites acceptance encompassing determining factors impacting students' intentions to use social network sites in the e-Learning system. This research sample involves the students of Palestine Technical University-Kadoorie under three branches in Palestine. The quantitative method of data collecting using a questionnaire survey is used in the present study. 370 Palestinian students were selected as the samples of the study using stratified random sampling. Regarding the number of the samples, Structural Equation Modeling (SEM) analysis, need at least 100 samples [56]. Also, using smart PLS path modeling recommends that the size of the sample should be a least 30 to 100 cases [56]. So, 370 respondents are satisfactory.

The survey used for data collection was adopted from earlier studies on the context of the information system. It includes 30 items adapted to the context of this study. The items used to measuring perceive enjoyment adopted from [57], [58], and [59]. The items measuring perceived usefulness, perceived ease of use and intention to use social media were adopted from [30], [60], and [61]. The items were measuring social influence adopted from [62], [63]. The items to measure perceive information security adopted from [47]. The respondent requests to choose one of the five-point Likert-scale ranging from (1) strongly disagree to (5) strongly agree. The online survey dispersed to students in Palestine Technical University-Kadoorie in West Bank, Palestine. The questionnaire survey also translated into the Arabic language 
as a native language of students to increase their understanding and respond efficiently. However, only 350 questionnaires are for data analysis. The data were analysed using the SEM approach through smart PLS 3 software.

\section{DATA ANALYSIS AND RESUltS}

The data analysis in this study was employed using SPSS version 22 and Smart PLS version 3. The SPSS was used to obtain the descriptive statistics of the sample while the investigation of the latent variable within the causal structure was employed using Smart PLS. The statistical analysis results are presented in the next subsections.

\section{A. Descriptive Statistics}

The features of the suspects and the constructs' descriptive statistics are presented in Table I and Table II, respectively. From Table II, the range of the mean of the entire construct was from 3.20 to 4.17 , with standard deviations ranging from 0 . .64 to .78. This showed a narrow spread of the values around the mean. Furthermore, the skewness values ranged from -.950 to -.159 , while the kurtosis values ranged from -.268 to 1.839 . The rule of thumb for skewness and kurtosis as established by Byrne [64] for normally distributed data are \pm 3 and \pm 7 , respectively and based on this recommendation, the data for this study were assumed to be suitable and regular for further analysis.

TABLE. I. SAMPLE CHARACTERISTICS

\begin{tabular}{|c|c|c|c|}
\hline $\begin{array}{l}\text { Sample } \\
\text { Characteristics }\end{array}$ & Items & Frequency & Percent (\%) \\
\hline \multirow{2}{*}{ Gender } & Male & 64 & $18 \%$ \\
\hline & Female & 286 & $82 \%$ \\
\hline \multirow{4}{*}{ Age } & $18-24$ years & 331 & $95 \%$ \\
\hline & $25-35$ years & 9 & $3 \%$ \\
\hline & $36-44$ years & 8 & $2 \%$ \\
\hline & 45 and above & 2 & $1 \%$ \\
\hline \multirow{3}{*}{ Education } & Diploma & 56 & $16 \%$ \\
\hline & Bachelor & 278 & $79 \%$ \\
\hline & Master & 16 & $5 \%$ \\
\hline \multirow{3}{*}{ Branch } & Tulkarm & 268 & $77 \%$ \\
\hline & Ramallah & 45 & $13 \%$ \\
\hline & Hebron & 37 & $11 \%$ \\
\hline \multirow{8}{*}{$\begin{array}{l}\text { The most used } \\
\text { social network } \\
\text { sites }\end{array}$} & Facebook & 146 & $42 \%$ \\
\hline & WhatsApp & 85 & $24 \%$ \\
\hline & YouTube & 17 & $5 \%$ \\
\hline & Instagram & 83 & $24 \%$ \\
\hline & Telegram & 2 & $1 \%$ \\
\hline & Twitter & 3 & $1 \%$ \\
\hline & Snapchat & 13 & $4 \%$ \\
\hline & Others & 1 & $0 \%$ \\
\hline \multirow{4}{*}{$\begin{array}{l}\text { Time spent on } \\
\text { social network } \\
\text { sites per day }\end{array}$} & Less than $1 \mathrm{~h}$ & 10 & $3 \%$ \\
\hline & $2-3 \mathrm{~h}$ & 86 & $25 \%$ \\
\hline & $4-5 \mathrm{~h}$ & 121 & $35 \%$ \\
\hline & $6 \mathrm{~h}$ and above & 133 & $38 \%$ \\
\hline
\end{tabular}

TABLE. II. DESCRIPTIVE STATISTICS

\begin{tabular}{|l|l|l|l|l|l|l|}
\hline Construct & INTU & PEOU & PE & PIS & PU & SI \\
\hline Items & 5 & 5 & 5 & 5 & 5 & 5 \\
\hline Mean & 3.860 & 4.170 & 3.880 & 3.200 & 3.660 & 3.470 \\
\hline S.D. & 0.780 & 0.560 & 0.660 & 0.780 & 0.580 & 0.640 \\
\hline Skewness & -.680 & -.950 & -.720 & -.1590 & -.279 & -.562 \\
\hline Kurtosis & .986 & 1.839 & 1.331 & -.268 & .814 & 1.375 \\
\hline $\begin{array}{l}\text { Cronbach's } \\
\text { alpha }\end{array}$ & 0.818 & 0.830 & 0.859 & 0.813 & 0.730 & 0.763 \\
\hline
\end{tabular}

The measurement instrument was checked for internal consistency using Cronbach's Alpha, and the result of the assessment showed all the constructs to obtain Cronbach's Alpha values of more than 0.60 , indicating their high internal consistency [65]. These values showed a good correlation between the collections of items replies used to measure the study constructs [66].

\section{B. Model Analysis}

The partial least squares version 3 (PLS 3) was used during the model verification to analyse the data. There are two stages in structural equation modeling using PLS; these are measurement model assessment and structural model assessment [67]. During the measurement model assessment stage, the constructs are examined for reliability and validity, while structural model assessment focuses on the verification of the model hypotheses.

1) Measurement model result: Hair [67] stated that the verification of the survey for the measurement model is an aspect of the PLS technique. This process is often implemented based on formative and reflective constructs. The goodness of measures is tested using two significant criteria - reliability and validity. Reliability implies testing the consistency of a given proposed instrument in measuring a specific aspect it was intended to measure. At the same time, validity implies testing the efficiency of a given instrument in measuring a specific concept it was designed to measure [68]. This study employing the three-elements procedure to assess the measurement model: Indicator items reliability, convergent validity, and discriminant validity. As per Hair [67], the minimum acceptable level of item loading must be > 0.60; however, for this study, the minimum acceptable item loading level was 0.60 .

As depicted in Fig. 2, 30 reflective indicators were used to test the measurement model. Also, three items (PU2, INTU1, PIS5) were found to have a factor loading of 0.594 and 0.671 , respectively. According to Hair [69], any item with a factor loading value in the range of 0.40 to 0.70 should be excluded as far as its exclusion will improve the composite reliability result (CR) above the recommended threshold value. Hence, the removal of the indicators was done in this study by performing the PLS algorithm test.

The Average Variance Extracted (AVE) was used as the basis to test the convergent validity for each construct shown in Table III. Convergent validity is a measure of the extent of the 
positive correlation between a measure and the other measures of the same construct [67]. This study adopted 0.5 as the minimum acceptable AVE value as earlier suggested by Hair [67]. The results proved that "Perceived Enjoyment" presented the highest AVE value (0.647) while "Social Influence" presented the lowest AVE value (0.516). These are all acceptable values concerning their convergent validity.

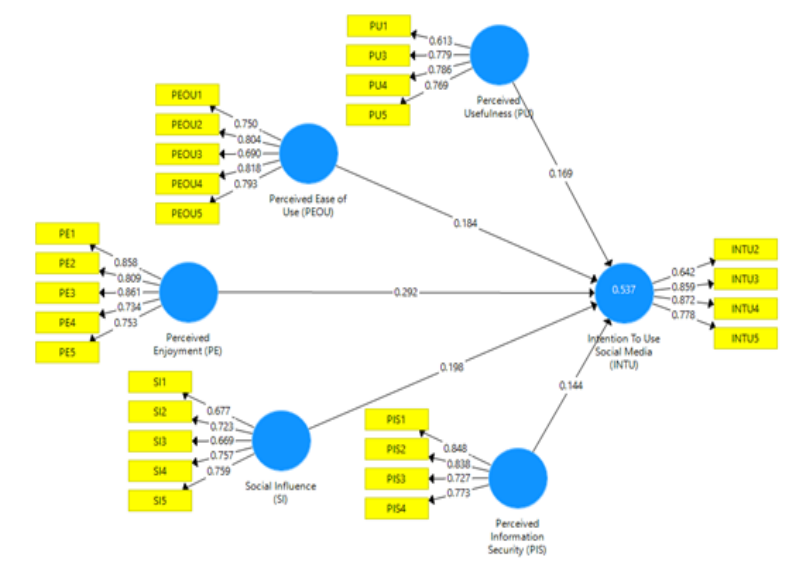

Fig. 2. Measurement Model.

TABLE. III. RELIABILITY AND VALIDITY RESULTS

\begin{tabular}{|c|c|c|c|c|c|}
\hline Construct & Items & Factor & Construct & Items & Factor \\
\hline \multirow{4}{*}{$\begin{array}{l}\text { Intention to } \\
\text { Use (INTU) }\end{array}$} & INTU2 & 0.642 & \multirow{4}{*}{0.629} & \multirow{4}{*}{0.870} & \multirow{4}{*}{0.809} \\
\hline & INTU3 & 0.859 & & & \\
\hline & INTU4 & 0.872 & & & \\
\hline & INTU5 & 0.778 & & & \\
\hline \multirow{5}{*}{$\begin{array}{l}\text { Perceived } \\
\text { Enjoyment } \\
\text { (PE) }\end{array}$} & PE1 & 0.858 & \multirow{5}{*}{0.647} & \multirow{5}{*}{0.901} & \multirow{5}{*}{0.870} \\
\hline & PE2 & 0.809 & & & \\
\hline & PE3 & 0.861 & & & \\
\hline & PE4 & 0.734 & & & \\
\hline & PE5 & 0.753 & & & \\
\hline \multirow{5}{*}{$\begin{array}{l}\text { Perceived } \\
\text { Ease of Use } \\
\text { (PEOU) }\end{array}$} & PEOU1 & 0.750 & \multirow{5}{*}{0.597} & \multirow{5}{*}{0.881} & \multirow{5}{*}{0.841} \\
\hline & PEOU2 & 0.804 & & & \\
\hline & PEOU3 & 0.690 & & & \\
\hline & PEOU4 & 0.818 & & & \\
\hline & PEOU5 & 0.793 & & & \\
\hline \multirow{4}{*}{$\begin{array}{l}\text { Perceived } \\
\text { Information } \\
\text { Security } \\
\text { (PIS) }\end{array}$} & PIS1 & 0.848 & \multirow{4}{*}{0.636} & \multirow{4}{*}{0.875} & \multirow{4}{*}{0.811} \\
\hline & PIS2 & 0.838 & & & \\
\hline & PIS3 & 0.727 & & & \\
\hline & PIS4 & 0.773 & & & \\
\hline \multirow{4}{*}{$\begin{array}{l}\text { Perceived } \\
\text { Usefulness } \\
\text { (PU) }\end{array}$} & PU1 & 0.613 & \multirow{4}{*}{0.548} & \multirow{4}{*}{0.828} & \multirow{4}{*}{0.715} \\
\hline & PU3 & 0.779 & & & \\
\hline & PU4 & 0.786 & & & \\
\hline & PU5 & 0.769 & & & \\
\hline \multirow{5}{*}{$\begin{array}{l}\text { Social } \\
\text { Influence } \\
\text { (SI) }\end{array}$} & SI1 & 0.677 & \multirow{5}{*}{0.516} & \multirow{5}{*}{0.842} & \multirow{5}{*}{0.776} \\
\hline & SI2 & 0.723 & & & \\
\hline & SI3 & 0.669 & & & \\
\hline & SI4 & 0.757 & & & \\
\hline & SI5 & 0.759 & & & \\
\hline
\end{tabular}

TABLE. IV. FORNELL-LARCKER CRITERION AND HETEROTRAITMONOTRAIT RATIO

\begin{tabular}{|c|c|c|c|c|c|c|}
\hline & $\begin{array}{l}\text { INT } \\
\text { U }\end{array}$ & $\begin{array}{l}\text { PEO } \\
\mathrm{U}\end{array}$ & PE & PIS & $\mathbf{P U}$ & SI \\
\hline \multicolumn{7}{|l|}{$\begin{array}{l}\text { Fornell-Larcker } \\
\text { Criterion }\end{array}$} \\
\hline $\begin{array}{l}\text { Intention To Use Social } \\
\text { Media (INTU) }\end{array}$ & 0.793 & & & & & \\
\hline $\begin{array}{l}\text { Perceived Ease of Use } \\
\text { (PEOU) }\end{array}$ & 0.520 & 0.772 & & & & \\
\hline $\begin{array}{l}\text { Perceived Enjoyment } \\
\text { (PE) }\end{array}$ & 0.606 & 0.498 & 0.805 & & & \\
\hline $\begin{array}{l}\text { Perceived Information } \\
\text { Security (PIS) }\end{array}$ & 0.427 & 0.322 & 0.308 & 0.798 & & \\
\hline $\begin{array}{l}\text { Perceived Usefulness } \\
\text { (PU) }\end{array}$ & 0.566 & 0.430 & 0.528 & 0.376 & 0.740 & \\
\hline Social Influence (SI) & 0.542 & 0.364 & 0.453 & 0.354 & 0.556 & 0.718 \\
\hline \multicolumn{7}{|l|}{$\begin{array}{l}\text { Heterotrait-Monotrait } \\
\text { Ratio } \\
\end{array}$} \\
\hline $\begin{array}{l}\text { Intention to Use Social } \\
\text { (INTU) }\end{array}$ & - & & & & & \\
\hline $\begin{array}{l}\text { Perceived Ease of Use } \\
\text { (PEOU) }\end{array}$ & 0.626 & - & & & & \\
\hline $\begin{array}{l}\text { Perceived Enjoyment } \\
\text { (PE) }\end{array}$ & 0.726 & 0.578 & - & & & \\
\hline $\begin{array}{l}\text { Perceived Information } \\
\text { Security (PIS) }\end{array}$ & 0.537 & 0.391 & 0.366 & - & & \\
\hline $\begin{array}{l}\text { Perceived Usefulness } \\
\text { (PU) }\end{array}$ & 0.739 & 0.528 & 0.658 & 0.495 & - & \\
\hline Social Influence (SI) & 0.688 & 0.440 & 0.554 & 0.456 & 0.747 & - \\
\hline
\end{tabular}

The discriminant validity of the examined constructs in this study was assessed using Fornell-Larcker and the HeterotraitMonotrait Ratio (HTMT) criterion, as presented in Table IV [70], [71]. Table IV showed a higher square root of the AVE compared to the construct correlation, suggesting the establishment of the discriminant validity. This further strengthened the HTMT assessment result where the discriminant validity was established with HTMT0.90. Generally, the results suggested adequate convergent and discriminant validities of the model.

The results for the six constructs based were all considered valid measures of their constructs with respect to their statistical significance and parameter estimates. The results generally indicate adequate empirical support of the model for its reliability, convergent and discriminant validities.

2) Evaluation of the structural model: In this study, the structural model or inner model portrays the correlation between the examined constructs. Therefore, the evaluation of the structural model portrays the relationship between the research hypotheses and their effects on studied constructs. In this regard, the path coefficient (ß) criterion was used to test the postulated hypotheses in this study. The range of the standardised values for path coefficient is between -1 and +1 ; values closer to +1 implies a strong relationship between every two constructs and vice versa [67]. When assessing the significant level of relationships using path coefficient value, the t-value is usually higher than a specific critical value, indicating a significant coefficient at a given error probability. For instance, $\mathrm{t}$-value $>1.96$ indicates a significance level at $\mathrm{p}$ $<0.05$. 
Table V showed that the results obtained from the research hypotheses tests were all acceptable. Specifically, the results of the first hypothesis (H1), which states that 'Perceived Usefulness (PU)' significantly influences on the 'intention to use social networks sites (INTU)'. This is based on evidence provided from that survey data with the result $(\beta=0.169, \mathrm{t}=$ 3.471, P-value<0.01) since the $t$-value is more than 1.96 , the hypothesis is therefore accepted. Furthermore, the second hypothesis (H2) assumed that 'Perceived Ease of Use (PEOU)' had a positive influence on 'Intention to Use Social networks sites (INTU)' and this hypothesis was accepted $(\Omega=0.184, \mathrm{t}=$ $3.873, \mathrm{p}<0.01)$. For the third hypothesis $(\mathrm{H} 3)$, the significant influence of 'Perceived Enjoyment (PE)' on 'Intention to Social networks sites (INTU)' was also supported by the results $(B=0.292, \mathrm{t}=5.540, \mathrm{p}<0.01)$. Likewise, the fourth hypothesis (H4), which states that 'Social Influence (SI)' positively influences 'Intention to Use Social network sites (INTU)', was also supported by our survey data with values ( $\beta$ $=0.198, \mathrm{t}=3.890, \mathrm{P}$-value $<0.091)$. And $(\mathrm{H} 5)$ which proposed a significant influence of 'Perceived Information Security (PIS) on the 'Intention to Use Social Media (INTU)' was also supported by the results $(\beta=0.144, \mathrm{t}=3.263, \mathrm{p}<0.01)$.

In this study, the coefficient of determination $\left(\mathrm{R}^{2}\right)$ value was also used to test the research hypotheses. As per Mitchell [72], $\mathrm{R}^{2}$ values in the range of $0.01-0.09$ are said to be low while those in the range of $0.09-0.25$ are moderate; those in the range of $0.25-1$ are high. Fig. 1 showed the results of the calculated $R^{2}$ values in this study. The calculated value $\left(R^{2}\right)$ of the image was 0.537 , indicating that $53.7 \%$ of the variances in Intention to Use Social Network Sites (INTU). Where explained by the five constructs, Perceived Ease of Use (PEOU), Perceived Enjoyment (PE), Perceived Information Security (PIS), Perceived Usefulness (PU), Social Influence (SI).

TABLE. V. HyPOTHESIS TESTING RESUlts

\begin{tabular}{|l|l|l|l|l|l|}
\hline$\#$ & Hypothesis & $\begin{array}{l}\text { Original } \\
\text { Sample } \\
(\mathbf{O})\end{array}$ & $\begin{array}{l}\text { T Statistics } \\
(\mid \mathbf{O} / \text { STDEV|) }\end{array}$ & $\begin{array}{l}\text { P. } \\
\text { Values }\end{array}$ & Results \\
\hline H1 & PU $\rightarrow$ INTU & 0.169 & 3.471 & 0.001 & Supported \\
\hline H2 & PEOU $\rightarrow$ INTU & 0.184 & 3.873 & 0.000 & Supported \\
\hline H3 & PE $\rightarrow$ INTU & 0.292 & 5.540 & 0.000 & Supported \\
\hline H4 & SI $\rightarrow$ INTU & 0.198 & 3.890 & 0.000 & Supported \\
\hline H5 & PIS $\rightarrow$ INTU & 0.144 & 3.263 & 0.001 & Supported \\
\hline
\end{tabular}

\section{DISCUSSION}

This study examines student's acceptance of social network sites in e-Learning using perceived usefulness and perceived ease of use as adopted from TAM, in addition to the perceived enjoyment, social influence, and perceived information security based on literature review. All the postulates in the research model were supported.

The results of the factors that affect student's acceptance of social network sites in e-Learning revealed perceived usefulness (H1) significantly and positively affect the student's acceptance of social network sites in e-Learning $(B=0.166, t=$ 2.667, $\mathrm{p}<0.05)$. This result can be interpreted as when the students have more perceived usefulness; they will be more accepting of social network sites in e-Learning. Therefore, perceived usefulness is an indispensable factor to stimulate the students to accept social network sites in e-Learning. The results were consistent with the study of Al-Rahmi [42] who found a positive and significant association among perceived usefulness and social network sites in learning the Quran and Hadith. Sago [73] also found that the frequency usage of social network sites is positively impacted by the level of perceived usefulness provided by social network sites services. Likewise, Ramirez [74] found that perceived usefulness is positively associated with the use of social network sites. Furthermore, Al-Sharafi [79], found that perceived usefulness is positively associated with the user intention to use internet banking services.

Similarly, perceived ease of use (H2) was identified as a significant factor that is associated with the acceptance of social network sites in e-Learning $(B=0.182, \mathrm{t}=2.794, \mathrm{p}<$ $0.05)$. This result can be interpreted as when the students have more perceived ease of use, and they will be more accepting of social network sites in e-Learning. Therefore, perceived ease of use is an indispensable factor to stimulate the students to accept social network sites in e-Learning. The results were consistent with the study of Al-Rahmi [42] who found a positive and significant association among perceived usefulness and social network sites in learning the Quran and Hadith. Similarly, Ramirez [74] found that perceived ease of use is a reliable prognosticator of social networks sites usage. Additionally, [76] indicated that perceived ease of use had positive effects on managers' intention to adopt e-commerce services.

Perceived enjoyment (H3) factor significantly and positively affect on the student's acceptance of social network sites in e-Learning $(\beta=0.261, \mathrm{t}=4.633, \mathrm{p}<0.05)$. This result can be interpreted as when the students have more perceived enjoyment; they will be more accepting of social network sites in e-Learning. Therefore, perceived enjoyment is an indispensable factor to stimulate the students to accept social network sites in e-Learning. Therefore, if they find social network sites enjoyable, amusing, entertaining, and pleasant in completing their transactions effectively and efficiently, they will feel the impulse to use it in e-Learning. A result consistent with prior findings of Sledgianowski [75] found a positive influence of perceived enjoyment on social network sites adoption behaviour and Al-Rahmi [42] who found a positive and significant association among perceived enjoyment and social network sites in the context of learning Quran and Hadith.

The results as well showed that social influence (H4) supported the positive effect on the student's acceptance of social network sites in e-Learning $(\beta=0.231, \mathrm{t}=4.828, \mathrm{p}<$ 0.05 ). Based on this result, it is expected that an individual's beliefs in virtual communities may affect a student's intention to use social network sites in e-Learning. Thus, educational institutions policymaker can exploit the positive effect of social influence in supporting social media networks use in eLearning. A result is harmonised with previous findings of [77], who found that social influence has a positive impact on behavioral intention. Moreover, perceived information security (H5) was identified as a significant factor that is associated with the acceptance of social network sites in e-Learning $(ß=$ $0.204, \mathrm{t}=5.161, \mathrm{p}<0.05)$. A result is matched with the study of [78], who found that information security positively impacts 
trust in E-government acceptance. Therefore, the students more perceived information security follows a tremendous student's acceptance of social network sites in e-Learning, meaning high perceived information security attracts students to use the eLearning system. Consequently, perceived information security is a crucial factor to motivate the students to accept social network sites in e-Learning.

\section{A. Theoretical and Practical Implications}

The theoretical contribution is the particular implications of the results for the current theory associated with the social networks sites and e-Learning. In this study, a research model proposed to study the factors that influence students' acceptance of social network sites in e-Learning; thus, there are three theoretical implications. Firstly, the study made use of perceived ease of use, and perceived usefulness in addition to perceived enjoyment, social influence, and perceived information security based on a literature review to study the factors affects student's acceptance of social network sites in e-Learning. Secondly, there is a vast difference among the extent of positive insights of social networks sites and the extent of applied usage. Besides, there is a lack of studies on users' perspectives on similar technologies in developing countries.

Furthermore, no research until now has studied social networks sites acceptance in e-Learning in Palestine via the combination of perceived ease of use, and perceived usefulness, perceived enjoyment, social influence, and perceived information security. This study addressed this issue by derives the theories forming the base of the creation of the research model and proposing to determine the factors that affect the acceptance of social network sites in e-Learning at Palestine Technical University-Kadoorie. Thirdly, the research model can add to the existing social network sites and eLearning literature.

Conversely, the current study also has practical implications. The first of which is the results of this study can be utilised by educational institutions policymakers to develop their educational strategies to benefit their institutions effectively. Secondly, technology developers at educational institutions may make use of the results and provide higher priority to perceived ease of use, perceived usefulness, perceived enjoyment, social influence, and perceived information security to increase student's acceptance of social networks sites in e-Learning. Thirdly, the survey used in this study agreed to the significant influence of (perceived ease of use, perceived usefulness, perceived enjoyment, social influence, and perceived information security) on student's acceptance of social network sites in e-Learning in Palestine. As well as, there is no research until now has studied social networks sites acceptance in e-Learning in Palestine. The result of this study should, therefore, support educational institutions policymakers and officials when taking stands on strategies to facilitate the effective use of social networks sites in e-Learning.

\section{B. Limitation of the Study and Future Research}

It is the interest of the current study to determine factors for the acceptance of social network sites in e-Learning. However, despite the contributions of the current study, some limitations still exist, which must be addressed. Firstly, the model used in the study includes two factors from TAM [30]; these factors are perceived usefulness and perceived ease of use with perceived enjoyment, social influence, and perceived information security as per the literature review. Regardless of the number of factors, their determination remains one of the limitations of the study because there are other factors that may affect a student's acceptance of social media networking in eLearning. Secondly, the study sample was collected from undergraduate students in Palestine Technical UniversityKadoorie. This sample may not adequately represent all the universities in Palestine.

Consequently, this result should not be generalised to the whole country in future studies. Thirdly, the present study scope is within the state of Palestine Technical UniversityKadoorie; hence, the other universities, colleges, and educational institutions should be considered in future studies. Fourthly, this study cannot be generalised to all developing countries, as most of them may not share demographic features with Palestine. Therefore, further studies should be conducted in different countries to validate and strengthen the results of this study. The results of this study might help other researchers in shaping subjects to highlight, to hearten progress in social network sites acceptance in e-Learning.

\section{CONCLUSION}

Widespread usage of social network sites has attracted the care of learning institutions in the world. Social networks sites offer exceptional learning that relies on participative communications as alternates for traditional learning. Moreover, social network sites offer more great chances for sharing capabilities that see further experiments that exploit these advantages, encouraging the creative and innovative skills of learners. Social network sites thereby represent an appropriate environment for the types of sophisticated educational sceneries that can suit the necessities of contemporary learners, consistent with universal technical progress.

The significant contribution of the current research is the development of a model for social network sites acceptance, including shaping factors that impact students' intentions to use social network sites in e-Learning for studying the research objective. This model is a coherent model that can be used in future empirical studies in the same field; the model can also be extended in different directions. The model developed in this research can guide further studies on student's acceptance of social network sites in e-Learning.

The results showed a positive and significant relationship among perceived usefulness, perceived, ease of use, perceived enjoyment, social influence, and perceived information security and social networks sites acceptance in e-Learning. Based on these findings, the effect of these factors should be considered by researchers in the future and policymakers when trying to improve on the level of social networks sites acceptance in e-Learning in a developing country, including Palestine. Therefore, this study emphasised the prominence of social network sites as practical learning tools.

\section{ACKNOWLEDGMENT}

We would like to thanks Palestine Technical UniversityKadoorie for funding and supporting the publication of this research. 


\section{REFERENCES}

[1] J. Abbas, J. Aman, M. Nurunnabi, and S. Bano, "The Impact of Social Media on Learning Behavior for Sustainable Education: Evidence of Students from Selected Universities in Pakistan," Sustainability, vol. 11, no. 6, p. $1683,2019$.

[2] G. P.-K. Zachos, E.-A.; Anagnostopoulos, I., "Social Media Use in Higher Education: A Review," Education Science vol. 8, no. 4, 2018, doi: http://dx.doi.org/10.3390/educsci8040194.

[3] D. T. Hansen, The teacher and the world: A study of cosmopolitanism as education. Routledge, 2017.

[4] K. Bredl, Methods for analyzing social media. Routledge, 2017.

[5] E. Bagarukayo and B. Kalema, "Evaluation of elearning usage in South African universities: A critical review," International Journal of Education and Development using ICT, vol. 11, no. 2, 2015.

[6] P. Lakbala, "Barriers in implementing E-learning in Hormozgan University of Medical Sciences," Global journal of health science, vol. 8, no. 7, p. 83, 2016.

[7] A. Rhema and I. Miliszewska, "Analysis of student attitudes towards elearning: The case of engineering students in Libya," Issues in informing science and information Technology, vol. 11, no. 1, pp. 169-190, 2014.

[8] J. A. Larusson and R. Alterman, "Wikis to support the "collaborative" part of collaborative learning," International Journal of ComputerSupported Collaborative Learning, vol. 4, no. 4, pp. 371-402, 2009.

[9] P. A. Ertmer, T. J. Newby, W. Liu, A. Tomory, J. H. Yu, and Y. M. Lee, "Students' confidence and perceived value for participating in crosscultural wiki-based collaborations," Educational Technology Research and Development, vol. 59, no. 2, pp. 213-228, 2011.

[10] W. M. Al-rahmi, M. S. Othman, and M. A. Musa, "The improvement of students' academic performance by using social media through collaborative learning in Malaysian higher education," Asian Social Science, vol. 10, no. 8, p. 210, 2014.

[11] I. D. Keenan, J. D. Slater, and J. Matthan, "Social media: Insights for medical education from instructor perceptions and usage," MedEdPublish, vol. 7, 2018.

[12] M. N. Yakubu and S. Dasuki, "Assessing eLearning systems success in Nigeria: An application of the DeLone and McLean information systems success model," Journal of Information Technology Education: Research, vol. 17, pp. 183-203, 2018.

[13] N. Ameen, R. Willis, M. N. Abdullah, and M. Shah, "Towards the successful integration of e-learning systems in higher education in Iraq: A student perspective," British Journal of Educational Technology, vol. 50, no. 3, pp. 1434-1446, 2019.

[14] K. N. Shen and M. Khalifa, "Facebook usage among Arabic college students: preliminary findings on gender differences," 2010.

[15] A. Al-Azawei, "What Drives Successful Social Media in Education and E-Learning? A Comparative Study on Facebook and Moodle," Journal of Information Technology Education, vol. 18, 2019.

[16] Z. N. Khlaif and S. Farid, "Transforming learning for the smart learning paradigm: lessons learned from the Palestinian initiative," Smart Learning Environments, vol. 5, no. 1, p. 12, 2018.

[17] Y. K. Dwivedi et al., "Research on information systems failures and successes: Status update and future directions," Information Systems Frontiers, vol. 17, no. 1, pp. 143-157, 2015.

[18] K. Shraim and Z. Khlaif, "An e-learning approach to secondary education in Palestine: opportunities and challenges," Information Technology for Development, vol. 16, no. 3, pp. 159-173, 2010.

[19] S. Saidam, "Knowledge and e-governance building in conflict affected societies: Challenges and mechanisms," in Proceedings of the 1 st international conference on Theory and practice of electronic governance, 2007, pp. 341-344.

[20] M. Ahsan and M. Kumari, "Rumors and their controlling mechanisms in online social networks: A survey," Online Social Networks and Media, vol. 14, p. 100050, 2019.

[21] M. Badri, A. Al Nuaimi, Y. Guang, and A. Al Rashedi, "School performance, social networking effects, and learning of school children: Evidence of reciprocal relationships in Abu Dhabi," Telematics and Informatics, vol. 34, no. 8, pp. 1433-1444, 2017.
[22] A. Abdulahi, B. Samadi, and B. Gharleghi, "A study on the negative effects of social networking sites such as facebook among asia pacific university scholars in Malaysia," International Journal of Business and Social Science, vol. 5, no. 10, 2014.

[23] A. M. Elkaseh, K. W. Wong, and C. C. Fung, "Perceived ease of use and perceived usefulness of social media for e-learning in Libyan higher education: A structural equation modeling analysis," International Journal of Information \& Education Technology, vol.6,no.3,p.192, 2016.

[24] P. A. Ertmer, T. J. Newby, W. Liu, A. Tomory, J. H. Yu, and Y. M. Lee, "Students' confidence and perceived value for participating in crosscultural wiki-based collaborations," Educational Technology Research and Development, vol. 59, no. 2, pp. 213-228, 2011.

[25] S. Manca and M. Ranieri, "Implications of social network sites for teaching and learning. Where we are and where we want to go," Education and Information Technologies, vol.22,no.2,pp.605-622, 2017.

[26] H. Karajeh et al., "Social media networks and pedagogy at the University of Jordan," Education and Information Technologies, vol. 23, no. 5, pp. 2073-2090, 2018.

[27] D. Z. Dumpit and C. J. Fernandez, "Analysis of the use of social media in Higher Education Institutions (HEIs) using the Technology Acceptance Model," International Journal of Educational Technology in Higher Education, vol. 14, no. 1, p. 5, 2017.

[28] E. Cho and J. Son, "The effect of social connectedness on consumer adoption of social commerce in apparel shopping," Fashion and Textiles, vol. 6 , no. 1, p. 14, 2019.

[29] F. D. Davis, "Perceived usefulness, perceived ease of use, and user acceptance of information technology," MIS quarterly,pp.319-340, 1989.

[30] A. T. Shittu, K. B. Madarsha, N. S. N. AbduRahman, and T. B. T. Ahmad, "Determinants of social networking software acceptance: A multi-theoretical approach," Malaysian Online Journal of Educational Technology, vol. 1, no. 1, pp. 27-43, 2013.

[31] V. Venkatesh, M. G. Morris, G. B. Davis, and F. D. Davis, "User acceptance of information technology: Toward a unified view," MIS quarterly, pp. 425-478, 2003.

[32] J. Kalin, "Doing what comes naturally? Student perceptions and use of collaborative technologies," International Journal for the Scholarship of Teaching and Learning, vol. 6, no. 1, p. 10, 2012.

[33] M. H. Fagan, S. Neill, and B. R. Wooldridge, "Exploring the intention to use computers: An empirical investigation of the role of intrinsic motivation, extrinsic motivation, and perceived ease of use," Journal of Computer Information Systems, vol. 48, no. 3, pp. 31-37, 2008.

[34] T. Ramayah and J. Ignatius, "Impact of perceived usefulness, perceived ease of use and perceived enjoyment on intention to shop online," ICFAI Journal of Systems Management (IJSM), vol. 3, no. 3, pp. 36-51, 2005.

[35] X. Deng, W. J. Doll, A. R. Hendrickson, and J. A. Scazzero, "A multigroup analysis of structural invariance: an illustration using the technology acceptance model," Information \& Management, vol. 42, no. 5, pp. 745-759, 2005.

[36] S.-H. Liu, H.-L. Liao, and J. A. Pratt, "Impact of media richness and flow on e-learning technology acceptance," Computers \& Education, vol. 52, no. 3, pp. 599-607, 2009.

[37] J. M. Curran and M. L. Meuter, "Encouraging existing customers to switch to self-service technologies: put a little fun in their lives," Journal of Marketing Theory and Practice, vol. 15, no. 4, pp. 283-298, 2007.

[38] H. Van der Heijden, "User acceptance of hedonic information systems," MIS quarterly, pp. 695-704, 2004.

[39] R. G. Saadé, W. Tan, and F. Nebebe, "Impact of Motivation on Intentions in Online Learning: Canada vs China," Issues in Informing Science \& Information Technology, vol. 5, 2008.

[40] F. D. Davis, R. P. Bagozzi, and P. R. Warshaw, "Extrinsic and intrinsic motivation to use computers in the workplace 1," Journal of applied social psychology, vol. 22, no. 14, pp. 1111-1132, 1992.

[41] C.-L. Hsu and J. C.-C. Lin, "Acceptance of blog usage: The roles of technology acceptance, social influence and knowledge sharing motivation," Information \& Management, vol.45, no. 1, pp. 65-74, 2008.

[42] W. M. Al-Rahmi and A. M. Zeki, "A model of using social media for collaborative learning to enhance learners' performance on learning," 
Journal of King Saud University-Computer and Information Sciences, vol. 29, no. 4, pp. 526-535, 2017.

[43] H.-T. Tsai and R. P. Bagozzi, "Contribution behavior in virtual communities: Cognitive, emotional, and social influences," Mis Quarterly, vol. 38, no. 1, pp. 143-164, 2014.

[44] R. L. Thompson, C. A. Higgins, and J. M. Howell, "Personal computing: toward a conceptual model of utilization," MIS quarterly, pp. 125-143, 1991.

[45] Y. Wang, D. B. Meister, and P. H. Gray, "Social influence and knowledge management systems use: Evidence from panel data," Mis Quarterly, pp. 299-313, 2013.

[46] A. Maryam, N. Maarop, R. Ibrahim, and M. Hasan, "Towards a model for studying social media adoption for the co-creation services domain," Indian Journal of Science and Technology, vol. 9, p. 34, 2016.

[47] S. Akter and S. F. Wamba, "Big data analytics in E-commerce: a systematic review and agenda for future research," Electronic Markets, vol. 26, no. 2, pp. 173-194, 2016.

[48] X. Luo, A. Gurung, and J. P. Shim, "Understanding the determinants of user acceptance of enterprise instant messaging: an empirical study," Journal of organizational computing and electronic commerce, vol. 20, no. 2, pp. 155-181, 2010.

[49] I. Achumba, O. Ighomereho, and M. Akpor-Robaro, "Security challenges in Nigeria and the implications for business activities and sustainable development," Journal of economics and sustainable development, vol. 4, no. 2, 2013.

[50] S. Byabato and K. Kisamo, "Implementation of school based continuous assessment (CA) in Tanzania ordinary secondary schools and its implications on the quality of education," Developing Country Studies, vol. 4, no. 6, pp. 55-61, 2014.

[51] C. Jewitt, C. Hadjithoma-Garstka, W. Clark, S. Banaji, and N. Selwyn, "School use of learning platforms and associated technologies-case study: secondary school 1," 2010.

[52] S.-C. Yang and C.-H. Lin, "Factors affecting the intention to use Facebook to support problem-based learning among employees in a Taiwanese manufacturing company," African Journal of Business Management, vol. 5, no. 22, pp. 9014-9022, 2011.

[53] M. M. Abbad, D. Morris, and C. De Nahlik, "Looking under the bonnet: Factors affecting student adoption of e-learning systems in Jordan," The International Review of Research in Open and Distributed Learning, vol 10, no. 2, 2009.

[54] Y.-C. Lee, "An empirical investigation into factors influencing the adoption of an e-learning system," Online information review, vol. 30, no. 5, pp. 517-541, 2006.

[55] S. Y. Park, "An analysis of the technology acceptance model in understanding university students' behavioral intention to use elearning," Educational technology \& society, vol. 12, no. 3, pp. 150-162, 2009.

[56] M. Luthfihadi and W. Dhewanto, "Technology Acceptance of Ecommerce in Indonesia," International Journal of Engineering Innovation and Management, vol. 3, pp. 9-18, 2013.

[57] M. MäNtymäKi and J. Salo, "Teenagers in social virtual worlds: Continuous use and purchasing behavior in Habbo Hotel," Computers in Human Behavior, vol. 27, no. 6, pp. 2088-2097, 2011.

[58] H. Nysveen, P. E. Pedersen, and H. Thorbjørnsen, "Intentions to use mobile services: Antecedents and cross-service comparisons," Journal of the academy of marketing science, vol. 33, no. 3, pp. 330-346, 2005.

[59] S. Moghavvemi, M. Sharabati, T. Paramanathan, and N. M. Rahin, "The impact of perceived enjoyment, perceived reciprocal benefits and knowledge power on students' knowledge sharing through Facebook," The International Journal of Management Education, vol. 15, no. 1, pp. 1-12, 2017.

[60] M. D. Dzandu, H. Boateng, G. Agyemang, and F. Quansah, "Social media adoption among University Students: What is the role of gender, perceived usefulness and perceived ease of use," International Journal of Social Media and Interactive Learning Environments, 2016.

[61] C. Lorenzo-Romero and M.-d.-C. Alarcón-del-Amo, "Segmentation of users of social networking websites," Social Behavior and Personality: an international journal, vol. 40, no. 3, pp. 401-414, 2012.

[62] M. Abdekhoda, A. Dehnad, S. J. G. Mirsaeed, and V. Z. Gavgani, "Factors influencing the adoption of E-learning in Tabriz University of Medical Sciences," Medical journal of the Islamic Republic of Iran, vol. 30, p. 457, 2016.

[63] K. Mzava and E. A. Kalinga, "Determinants of Nurses'intention to Use Elearning in Tanzania," Journal of Health Informatics in Developing Countries, vol. 11, no. 2, 2017.

[64] B. M. Byrne, Structural equation modeling with LISREL, PRELIS, and SIMPLIS: Basic concepts, applications, and programming. Psychology Press, 2013.

[65] J. C. Nunnally, Psychometric theory 3E. Tata McGraw-Hill Education, 1994.

[66] D. Andrew, P. Pedersen, and C. McEvoy, "Research methods and design in sport management," Research methods and design in sport management, 2011.

[67] J. F. Hair Jr, G. T. M. Hult, C. Ringle, and M. Sarstedt, A primer on partial least squares structural equation modeling (PLS-SEM). Sage publications, 2016.

[68] U. Sekaran, and R. Bougie (2003). "Research methods for business, a skill building approach", John Willey \& Sons," Inc. New York.

[69] J. F. Hair, C. M. Ringle, and M. Sarstedt, "PLS-SEM: Indeed a silver bullet," Journal of Marketing theory and Practice, vol. 19, no. 2, pp. 139152, 2011.

[70] C. Fornell and D. F. Larcker, "Evaluating structural equation models with unobservable variables and measurement error," Journal of marketing research, vol. 18, no. 1, pp. 39-50, 1981.

[71] J. Henseler, C. M. Ringle, and M. Sarstedt, "A new criterion for assessing discriminant validity in variance-based structural equation modeling," Journal of the academy of marketing science, vol. 43, no. 1, pp. 115-135, 2015.

[72] M. L. Mitchell, and J. M. Jolley (2012). Research design explained: Cengage Learning.

[73] B. Sago, "Factors influencing social media adoption and frequency of use: An examination of Facebook, Twitter, Pinterest and Google+," International Journal of Business and Commerce, vol. 3, no. 1, pp. 1-14, 2013.

[74] P. Ramírez-Correa, E. E. Grandón, M. Ramírez-Santana, and L. Belmar Ordenes, "Explaining the use of social network sites as seen by older adults: The enjoyment component of a hedonic information system," International journal of environmental research and public health, vol. 16, no. 10, p. 1673, 2019.

[75] D. Sledgianowski and S. Kulviwat, "Social network sites: Antecedents of user adoption and usage," AMCIS 2008 Proceedings, p. 83, 2008.

[76] A. Herzallah and M. Mukhtar, "The Impact of Perceived Usefulness, Ease of Use and Trust on Managers' Acceptance of e-Commerce Services in Small and Medium-Sized Enterprises (SMEs) in Palestine," 2016.

[77] S. Chauhan, M. Jaiswal, and A. K. Kar, "The acceptance of electronic voting machines in India: a UTAUT approach," Electronic Government, an International Journal, vol. 14, no. 3, pp. 255-275, 2018.

[78] M. M. Ayyash, K. Ahmad, and D. Singh, "Investigating the effect of information systems factors on trust in e-government initiative adoption in Palestinian public sector," Research Journal of Applied Sciences, Engineering and Technology, vol. 5, no. 15, pp. 3865-3875, 2013.

[79] Al-Sharafi, A., Arshah, R. A., Alajmi, Q., Herzallah, A. T., \& Qasem, Y. A., "The Influence of Perceived Trust on Understanding Banks' Customers behavior to Accept Internet Banking Services", Indian Journal of Science and Technology, Vol 11(20), PP. 1-9, 2018. 